\title{
Feeding, growth, and fecundity of Capitella sp. I in relation to sediment organic concentration
}

\author{
Debra L. Linton*, Gary L. Taghon \\ Institute of Marine and Coastal Sciences, Rutgers, the State University of New Jersey, 71 Dudley Road, \\ New Brunswick, New Jersey 08901-8521, USA
}

\begin{abstract}
In marine soft-bottom benthic habitats, the disappearance of opportunistic species as succession proceeds following an enrichment or disturbance event is thought to be due to the exhaustion of a food resource. To further investigate this hypothesis, feeding rate, growth rate, and reproductive output (measured as embryo number and size) of the opportunistic deposit-feeding polychaete Capitella sp. I were measured in sediments with different protein concentrations but the same protein source. Feeding rates progressively increased as protein concentration increased over the range of 0.2 to $4.7 \mathrm{mg} \mathrm{g}^{-1}$; thereafter, feeding rate was constant up to a sediment protein concentration of $8.1 \mathrm{mg} \mathrm{g}^{-1}$, the highest used in these experiments. This response is not consistent with the predictions of optimal foraging theory, as applied to deposit feeders. Growth rate showed a similar pattern, progressively increasing then reaching a plateau at $\sim 23 \% \mathrm{~d}^{-1}$ in sediments with 4.6 to $4.7 \mathrm{mg}$ protein $\mathrm{g}^{-1}$. Capitella sp. I showed decreased fecundity and longer generation times (embryo sizes were not significantly different) in sediments with lower protein concentrations and did not reproduce in sediments containing $<1$ to $2 \mathrm{mg} \mathrm{g}^{-1}$. These results support the hypothesis that the disappearance of Capitella sp. I as succession proceeds is due to decreased fitness in sediments with lower food concentrations and an inability to reproduce in sediments below a threshold protein concentration. Systematically documenting how variations in sediment protein concentration affect the acquisition (feeding rate) and utilization (growth rate, reproductive output) of food resources by benthic invertebrates with different life-history strategies will help to elucidate important factors influencing the distribution of individuals and species in the benthos.
\end{abstract}

KEY WORDS: Capitella sp. I · Deposit-feeding $\cdot$ Feeding rate $\cdot$ Functional response $\cdot$ Growth rate Opportunistic species $\cdot$ Polychaetes $\cdot$ Sediment organic concentration

Resale or republication not permitted without written consent of the publisher

\section{INTRODUCTION}

The dichotomy between opportunistic and equilibrium life-history strategies is one of the most basic paradigms in marine benthic ecology. Classification of deposit-feeding marine invertebrates along this continuum is based primarily on studies of benthic community succession following disturbance and/or organic enrichment (e.g. Grassle \& Grassle 1974, McCall 1977, Pearson \& Rosenberg 1978). Species that initially colonize disturbed areas have been termed 'oppor-

${ }^{*}$ E-mail: elinton@rci.rutgers.edu tunistic species'. They possess life-history adaptations that enable them to colonize disturbed or enriched sites quickly. Opportunists produce many broods per year, potentially providing a steady supply of larvae to colonize a disturbed site at any time. Once they arrive at the site, characteristics such as rapid individual growth, early maturity, brood protection, and lecithotrophic larvae allow opportunists to rapidly increase their population sizes (Grassle \& Grassle 1974, McCall 1977). As the site recovers, populations of these opportunists rapidly decline and a community of 'equilibrium species' becomes established. These latter species characteristically are slower growing, have few broods per year (or reproduce annually), produce 
planktotrophic larvae, have no brood protection, and have relatively stable population sizes (McCall 1977).

The rapid decline of opportunistic species does not appear to be due to competitive displacement by equilibrium species. Opportunists continue to dominate any organically enriched site, but experience population declines when enrichment stops, even in the absence of equilibrium species (Grassle \& Grassle 1974). The disappearance of opportunists, then, must be due to dramatic decreases in their fitness in response to changes in the environment when enrichment stops. Thistle (1981), after reviewing studies of natural disturbances, concluded that the disappearance of opportunistic species from aging disturbed patches may result from the exhaustion of adequate food supply. While no study has systematically documented the changes in sediment organic concentration during succession, fluctuation in available organic matter is acknowledged to be one of the principal causes of faunal change in nearshore benthic environments (Pearson \& Rosenberg 1978). Experimentation by various researchers on the population dynamics of the opportunistic polychaete Capitella sp. I has supported its suggested dependence on the supply of organic matter.

These previous studies with Capitella sp. I have shown that both the type of organic matter and the absolute amount of organic matter available per unit worm biomass (ration) can dramatically influence growth and reproduction (Tenore 1977, 1981, 1983, Tenore \& Chesney 1985, Grémare et al. 1988, 1989a,b, Marsh et al. 1989, Forbes \& Lopez 1990, Tsutsumi et al. 1990, Bridges et al. 1994, Forbes et al. 1994, Horng 1998). The concentration of organic matter is also important to the growth and reproduction of opportunists (Forbes et al. 1994, Horng 1998). Experimental evidence suggests that reproduction by Capitella sp. I may be restricted to areas where the sediments contain some threshold concentration of protein (Tsutsumi 1990, Tsutsumi et al. 1990, Horng 1998, Cohen \& Pechenik 1999).

While opportunistic species appear to be restricted to sediments with high concentrations of organic matter, equilibrium species are able to maintain populations in sediments with much lower concentrations. Clearly these 2 types of species have different adaptive strategies that lead to their differential success in different sediments. These adaptations may be behavioral, as well as physiological. For example, it has been suggested that some deposit feeders maximize their energy intake over a range of sediment qualities by altering their feeding rate in such a way as to maximize absorption of digestive products (Taghon 1981, Calow 1982, Phillips 1984, Cammen 1989, Dade et al. 1990). Optimal foraging theory developed for deposit feeders predicts maximum throughput rates at intermediate food concentrations (Dade et al. 1990). Feeding rates of the equilibrium deposit-feeding species Abarenicola pacifica show this functional response (Taghon \& Greene 1990, Taghon et al. 1990). This behavior may buffer them against dramatic changes in reproduction as sediment quality varies. Initial observations of feeding rate in Capitella sp. I are inconclusive. Forbes \& Lopez (1987) found no changes in the feeding rate in worms presented sediments of different quality, but subsequent experiments have shown that Capitella sp. I has different feeding rates in sediments with different organic concentrations (Forbes et al. 1994, Horng 1998). However, these previous experiments were not designed to test whether Capitella sp. I maximizes energy intake by altering feeding rate. Here, we present the results of experiments systematically measuring both behavioral (feeding rate) and physiological (growth rate, fecundity, egg size) fitness characteristics of an opportunistic species over a range of sediment protein concentration. By documenting how these characteristics vary as sediment protein concentration changes, we might gain insight into factors influencing the distribution of this species and of opportunistic species in general.

\section{MATERIALS AND METHODS}

Study species. Capitella sp. I (Grassle \& Grassle 1976) is a small deposit-feeding polychaete. Characteristic lengths are 20 to $40 \mathrm{~mm}$ and wet weights are on the order of 3 to $12 \mathrm{mg}$ (Grassle \& Grassle 1976). Individuals live in mucus-lined burrows and feed on surface and near-surface sediment (Levin 1984). Capitella sp. I has rapid individual growth $\left(>20 \% \mathrm{~d}^{-1}\right)$, a short generation time $\left(37\right.$ to $50 \mathrm{~d}$ at $15^{\circ} \mathrm{C}$ ), and many broods per year, allowing it to respond quickly to enrichment and disturbance and to achieve explosive population growth, often reaching densities on the order of $10^{4} \mathrm{~m}^{-2}$ (Grassle \& Grassle 1974: described as Capitella capitata and subsequently identified as Capitella sp. I [Grassle \& Grassle 1977]) to $10^{5} \mathrm{~m}^{-2}$ (J. Grassle pers. comm.). Reproductive characteristics for Capitella sp. I are well documented. Sexes are normally separate. Females are heterogametic, with homogametic individuals usually becoming males (rarely females). The homogametic males can subsequently develop into simultaneous hermaphrodites if females are rare (Grassle \& Grassle 1974, Holbrook \& Grassle 1984). Females produce broods of 30 to 400 eggs, each measuring 260 by $180 \mu \mathrm{m}$ (Grassle \& Grassle 1976, Levin 1984, Eckelbarger 1986), which are brooded in a tube created and ventilated by the female. The fertilized eggs develop into lecithotrophic larvae that are competent to settle almost immediately after being re- 
leased from the tube (Eckelbarger et al. 1984, Dubilier 1988).

Worms. Cultures of Capitella sp. I were established in our laboratory in spring, 1993, with worms obtained from cultures maintained in the laboratory of Dr J. P. Grassle at Rutgers University. Cultures were maintained at $15^{\circ} \mathrm{C}$ in a temperature-controlled environmental chamber. Worms were cultured in dishes (115 mm diameter $\times 50 \mathrm{~mm}$ height) with continuously aerated seawater (filtered $<1 \mu \mathrm{m}$ ) and a layer of sediment $\sim 5 \mathrm{~mm}$ thick. Approximately 50 worms were maintained in each dish. Worms were fed surface sediment collected from the intertidal zone of a Spartina alterniflora-dominated salt marsh on Delaware Bay. Sediment was sieved through a $1 \mathrm{~mm}$ mesh screen to remove large organisms and fragments of plant detritus, and was then stored at $-20^{\circ} \mathrm{C}$ and thawed as needed. Every 2 wk worms were sieved from the depleted sediments (mostly composed of fecal pellets) and replaced in freshly thawed sediment and clean seawater. Salinity was measured every 3 to $4 \mathrm{~d}$ and was maintained between 30 and $32 \%$ by addition of distilled water, as needed, to compensate for evaporation.

Worm measurement. Dry weights of Capitella sp. I in all experiments were estimated based on a regression curve relating worm width to dry weight. To develop this equation, Capitella sp. I individuals were held in seawater until feces were voided, then worms were anaesthetized by placing them in a $3 \%$ magnesium chloride solution. Width was measured at the fifth setiger (the maximum thoracic width) using an ocular micrometer on a stereo microscope at $56 \times$. The worms were subsequently dried and weighed. A power regression, correlating width to dry weight, was fit to the data using the statistical software StatView (SAS Institute, Inc., Cary, North Carolina). The regression equation was:

$$
\text { dry weight }=0.558(\text { width })^{2.945}\left(\mathrm{r}^{2}=0.907, \mathrm{n}=91\right)
$$

Apparatus. All experiments were conducted in a seawater table with a continuous flow of recirculated seawater and continuous aeration to prevent oxygen depletion. Temperature was maintained at $15^{\circ} \mathrm{C}$ for all experiments. Salinity was measured approximately every $2 \mathrm{~d}$ and maintained between 30 and $32 \%$ by addition of freshwater, as needed, to compensate for evaporation. For all experiments, small, sequentially numbered petri dishes $(50 \mathrm{~mm}$ diameter $\times 15 \mathrm{~mm}$ height) were used as containers. The dishes were randomly placed in the seawater table (based on a computer-generated random table) and treatment sediment was added by pipette the day before the worms were added.

Expt 1. Sediment preparation: Sediments were collected in October 1997 from the marsh surface at
Delaware Bay (the source of sediment used for maintaining the long-term cultures) and from an intertidal marsh creek adjacent to the Rutgers University Marine Field Station at Tuckerton, New Jersey. All sediments were initially sieved through a $1 \mathrm{~mm}$ mesh screen. Sediments were stored by freezing at $-20^{\circ} \mathrm{C}$ and thawed prior to use. Sediments for the experiment were further sieved to obtain the $<88 \mu \mathrm{m}$ size fraction. Based on previous measurements of the protein concentration of sediments from these sites, a stock sediment of 3:2 Tuckerton:Delaware Bay sediment was mixed, targeting a protein concentration of $\sim 8 \mathrm{mg} \mathrm{g}^{-1}$ sediment. This protein concentration was selected based on experiments by Horng (1998), in which feeding rate of Capitella sp. I decreased when sediment protein concentration was increased from 7.3 to $8.3 \mathrm{mg}$ $\mathrm{g}^{-1}$. Because we wanted the range of sediment protein concentration to be the same for both the feeding and reproduction experiments, this value was the target for the highest protein concentration in both experiments. A portion of this sediment mix was dried and baked at $375^{\circ} \mathrm{C}$ for $24 \mathrm{~h}$ to combust all organic matter. The baked sediment did not have any detrimental effect on Capitella sp. I larvae, juveniles, or adults in preliminary experiments. We believe that baking the sediments at a relatively low temperature over a longer period of time does not produce the toxic by-products which have sometimes been present after higher temperature baking $\left(\sim 500^{\circ} \mathrm{C}\right)$. The baked sediment was ground and re-sieved through an $88 \mu \mathrm{m}$-mesh screen. The baked and unbaked sediments were then mixed in proportions of $20,40,60,80$, and $100 \%$ unbaked sediment. The benefit of this method of producing sediment treatments is that the sediments represent a range of sediment protein concentration, while the source of protein is the same for all treatments within an experiment. This approach does not allow us to demonstrate conclusively that protein is the key factor (since all other components of the sediment will covary exactly). However, we believe that bioavailable protein is currently the best measure of sediment quality and that much can be learned from investigating how it correlates with different life-history parameters.

Sediment samples for chemical analysis were frozen, freeze-dried, and then homogenized by grinding. Total nitrogen (TN) and total carbon (TC) concentrations were measured using a Carlo Erba NA-1500 elemental analyzer (Valencia, California). Sediments were not exposed to $\mathrm{HCl}$ to remove inorganic carbon prior to analysis because shell fragments were not apparent in the twice-sieved sediments (the second at $<88 \mu \mathrm{m}$ ). We believe the measurement reflects total organic carbon (TOC) concentration; however, by convention, omission of the $\mathrm{HCl}$ treatment necessitates the use of the total carbon (TC) label. Protein concentration was 
measured using the 'Enzyme Hydrolyzable Amino Acids' (EHAA) technique of Mayer et al. (1995). This technique gives a biologically relevant measure of sediment protein concentration because it mimics the action of digestive enzymes and measures only that portion of organic matter that is available to be digested. Sediment chemistry measurements were plotted against mix percentage and a regression line was fit to the data. The regression equation was then used to determine the values of sediment chemistry to be used in the analyses. This procedure reduced the effect of any outlying data points.

Experimental design: Larvae were collected from $\sim 25$ isolated brooding females and pooled. Larvae were randomly taken from the pool by pipette and placed in culture dishes containing the treatment sediments. Approximately 100 larvae were added to each of 6 dishes per treatment. Larvae settled into the treatment sediments and metamorphosed into juvenile worms. The culture dishes served as nurseries in which the worms were reared until they reached sufficient size for them to be manipulated and assigned to replicate treatment dishes in the seawater table. These mass cultures were maintained at $15^{\circ} \mathrm{C}$ in 30 to $32 \%$ seawater with continuous aeration for $15 \mathrm{~d}$. At this time the worms were sieved out, sample worms from each treatment were fixed in $4 \%$ formaldehyde to provide an estimate of worm size on Day 15, and 5 worms were placed into each of 60 numbered petri dishes per treatment in the seawater table. Each dish contained a layer of treatment sediment approximately $2 \mathrm{~mm}$ deep. Throughout the 6 wk duration of the experiment, dishes were checked every other day to assess the degree of sediment depletion. Capitella sp. I fecal pellets are very robust and the difference between 'fresh' sediment and sediment that has already been ingested and pelletized is very distinct. Fresh sediment (which had been stored at $4^{\circ} \mathrm{C}$ to prevent degradation) was added as needed, well in advance of depletion, so that available sediment was never limiting. Possible changes in the protein concentration of uneaten sediment (e.g. due to bacterial degradation or selective feeding) could not be monitored; however, by periodically adding fresh sediment, we are confident that average available protein levels remained near the initial values and that differences between treatments were maintained. Based on previous experiments and our experience in culturing Capitella sp. I, we have found that the worms do not crawl out of their dishes if adequate food supply and oxygen concentration are maintained, and this was the case throughout this experiment.

Offspring production: On Days 23, 30, 37, 44, 51, and 58 (i.e weekly), 10 dishes per treatment were removed from the seawater table and the worms were sieved out, checked for the presence of embryos in brood tubes, and fixed in $4 \%$ formaldehyde. Samples were taken destructively because a preliminary experiment had shown that anaesthetizing and measuring the worms and then placing them back in the experiment resulted in a significant decrease in growth rates. When embryos were present in the brood tubes, they were also preserved in a vial with the female. Once females in a treatment began forming brood tubes containing larvae, all remaining dishes in that treatment were checked weekly (even those not being destructively sampled that week), and all brooding females were removed to prevent release of larvae into the seawater table. These females and brood tubes were also preserved and the date and dish were recorded. No attempt was made to distinguish between broods produced by true females and those produced by hermaphrodites.

For each brood tube, all embryos were counted and $25 \%$ of the embryos were measured. Maximum and minimum dimensions of the planar image of each embryo were measured at $56 \times$ using an ocular micrometer on a stereomicroscope. The sampling protocol resulted in preservation of the broods at different stages of development. Therefore, some of the embryos were still relatively spherical and early cell cleavage lines could still be seen, while those in more advanced development were more flat and elongated. Broods preserved early in development were noted so that ANOVA comparison of embryo sizes might be done on these cases separately. In all cases, statistical comparisons of embryo sizes were done on the area (maximum width $[\mathrm{mm}] \times$ minimum width $[\mathrm{mm}]$ ) of the planar image of the embryos. Although embryo size is a fairly coarse measurement of parental investment, Bridges (1996) found that there were marginal differences in embryo size (suggesting differential per offspring investment) for broods produced in different sediment treatments.

Growth: Preserved worms were measured and dry weights estimated for all sampling periods (as described above). Mean relative growth rates (RGR, $\% \mathrm{~d}^{-1}$ ) were calculated for each sampling period using Fisher's formula (Radford 1967):

$$
\operatorname{RGR}\left(\% \mathrm{~d}^{-1}\right)=\left[\left(\ln S_{2}-\ln S_{1}\right) / \Delta t\right] \times 100
$$

where $S_{1}=$ size at the beginning of the period, $S_{2}=$ size at the end of the period, and $\Delta t=$ time interval (days). For the first interval (Days 15 to 23), $S_{1}$ was estimated for each treatment as the average dry weight of the worms preserved on Day 15. The value of $S_{2}$ was calculated for each dish as the average dry weight of worms in that dish on the sampling date (Day 23). For each subsequent period, the average size of all worms 
within each treatment at the end of the previous interval was used as an estimate of $S_{1}$.

Expt 2. Sediment preparation: Sediment was collected from the marsh surface at Delaware Bay in July 1998. Sediment was initially sieved through a $1 \mathrm{~mm}$ mesh screen, and then sieved to $<88 \mu \mathrm{m}$. A portion of the sediment was baked at $375^{\circ} \mathrm{C}$ for $24 \mathrm{~h}$ to remove all organic matter. Based on previous measurements of the protein concentration of $<88 \mu \mathrm{m}$ Delaware Bay sediment, Gerber's oatmeal cereal for babies (ground and sieved $<88 \mu \mathrm{m}$ ) was added to the unbaked sediment in an amount sufficient to raise the protein concentration to $\sim 8 \mathrm{mg} \mathrm{g}^{-1}$. In the previous experiment (Expt 1) Tuckerton sediment was used to increase the protein concentration of the Delaware Bay sediment. However, that sediment mix did not reach the target protein concentration of $8 \mathrm{mg} \mathrm{g}^{-1}$. Instead, the protein concentration was only $5.7 \mathrm{mg} \mathrm{g}^{-1}$. By using cereal of a known, uniform protein concentration to enrich the Delaware Bay sediment, we hoped that we could more accurately control the protein concentration of the treatment sediment. The cereal was blended into the sediment with an egg-beater for $30 \mathrm{~min}$. This stock sediment was then diluted with the baked sediment in proportions of $12.5,25,37.5,50,62.5,75,87.5$, and $100 \%$ unbaked sediment. Sediment samples were taken and analyzed for chemical properties as previously described.

Experimental design: Larvae were collected from $\sim 10$ isolated brooding females and pooled together. Larvae were randomly taken from the pool by pipette and placed in culture dishes containing Delaware Bay $(<1 \mathrm{~mm})$ sediment. Approximately 100 larvae were added to each of 5 dishes. Larvae settled and metamorphosed into juvenile worms, which were reared at $15^{\circ} \mathrm{C}$ in 30 to $32 \%$ seawater with continuous aeration for $4 \mathrm{wk}$. At the end of this time, the worms were sieved out of the sediment and held in seawater for $\sim 20 \mathrm{~h}$. Five worms were then put into each of 8 petri dishes per treatment in the seawater table. Sample worms were also preserved in $4 \%$ formaldehyde at this time to provide an estimate of initial worm size. Each dish contained a layer of treatment sediment $\sim 2 \mathrm{~mm}$ deep. Dishes were checked every other day to assess the degree of sediment depletion. Throughout the $10 \mathrm{~d}$ duration of the experiment, sediment was not close to being depleted in any of the treatments. An air hose was positioned inside the lip of each dish to aerate water inside the dish and aid in mixing.

Feeding rate: After $10 \mathrm{~d}$ all dishes were collected. Worms were sieved out ( $300 \mu \mathrm{m}$ sieve) and preserved and the fecal pellets were collected. Because fecal pellets are too large to be re-consumed by the worms, and since such a small fraction of the sediment is removed during digestion, the weight of the fecal pellets is an acceptable measurement of the amount of sediment ingested. Fecal pellets in all treatments were normal in appearance and consistency (similar to pellets produced in natural sediments) and were not disrupted by the sorting and rinsing process. Pellets were collected by sorting the sediments over a $90 \mu \mathrm{m}$ sieve. Because all starting sediment particles were $<88 \mu \mathrm{m}$, they passed through the sieve and the material retained was almost entirely fecal pellets. The fecal pellets were gently rinsed in distilled water to remove salts. The fecal pellets were much larger than the sediment particles, so they settled almost immediately and the overlying water and any remaining sediment particles were poured off. This procedure was repeated at least twice. The fecal pellets were then dried and weighed. Average daily feeding rate $\left(\mathrm{mg} \mathrm{dish}^{-1} \mathrm{~d}^{-1}\right)$ was calculated for each dish as total weight of feces per dish divided by the number of days (10). Weight-specific feeding rates $\left(\mathrm{d}^{-1}\right)$ were calculated by dividing the total weight of feces produced per day by the total dry weight of all worms in the dish at the midpoint of the experiment (geometric mean size).

Growth: Relative growth rates $\left(\% \mathrm{~d}^{-1}\right)$ were calculated as in Expt 1. For this experiment, $S_{1}$ was estimated for all worms as the average dry weight of the worms preserved at the start of the experiment. The value of $S_{2}$ was calculated for each dish as the average dry weight of worms in that dish at the end of the experiment.

Statistical analysis. All statistics were calculated using StatView Version 5.0 and SuperANOVA Version 1.11 (SAS Institute, Inc., Cary, North Carolina). For ANOVA of worm sizes on Day 15 of Expt 1, individual worms were considered replicates. For all other analyses the averages of all worms in a dish were treated as replicates. Treatment effects on worm size, relative growth rate, embryo size, and specific feeding rate were compared using 1-way analysis of variance (ANOVA). Total feeding rates (mg dish ${ }^{-1} \mathrm{~d}^{-1}$ ) and number of embryos were analyzed using analysis of covariance (ANCOVA) in order to separate the effects of worm size from treatment effects. An alpha level of 0.05 was used as the criterion for rejecting the null hypothesis in all tests.

Dish total geometric mean size (mg dry weight) was used as the covariate in the feeding rate analysis. Geometric mean size (GMS) was estimated for each worm in a dish by the formula:

$$
\text { GMS (mg dry wt) }=\left(S_{1} \times S_{2}\right)^{1 / 2}
$$

where $S_{1}=$ size at the beginning of the period and $S_{2}=$ size at the end of the period. $S_{1}$ was estimated as the average dry weight of the worms preserved at the start of the experiment. Geometric mean sizes of all worms 
in a dish were then added to give an estimate of the total dry weight of worm tissue in each dish at the midpoint of the experiment. This is the value used as the covariate in the ANCOVA of feeding rate. Dry weights (mg) of the brooding females were used as the covariates for ANCOVA of embryo numbers.

The ANCOVA assumption of homogeneity of regression slopes (dependent variable vs covariate) was tested following the method of Huitema (1980). All ANCOVA presented fit the assumption of homogeneity of regression slopes. The assumption of homogeneity of variances was examined for all analyses by plotting residuals versus fitted values. If heterogeneity was found, data were transformed to stabilize the variances. Transformations are indicated in the relevant figure legends.

When significant main effects were detected in ANOVA, multiple comparisons of treatment means were performed using Fisher's protected least-significant-difference (LSD) test. Multiple comparisons of ANCOVA-adjusted treatment means were performed using the least-squares method.

Smoothed regression lines were fit to bivariate scatterplots using Cleveland's (1979, 1981) LOcallyWEighted Scatterplot Smoother (LOWESS). This is a robust procedure that diminishes the distorting effect of outliers by assigning greater weight to locally grouped data points. LOWESS fits were performed in StatView, using the default tension setting of $66 \%$.

\section{RESULTS}

\section{Expt 1}

Sediment chemistry

Values of sediment chemistry (based on linear regression) are listed in Table 1 . The coefficients of determination $\left(\mathrm{r}^{2}\right)$ for all regressions were $>0.95$. Changes in the $\mathrm{C} / \mathrm{N}$ ratios among treatments are most likely due to the differential removal of carbon and nitrogen by the baking procedure. Carbon levels are reduced by $>95 \%$, however nitrogen levels are reduced by only $~ 85 \%$. As the percentage of baked sediment in the treatments increases, the more nitrogen there is per unit carbon, and the $\mathrm{C} / \mathrm{N}$ ratio decreases. This phenomenon is also seen for Expt 2 sediments.

\section{Growth}

Significant differences in worm size (mass in $\mathrm{mg}$ ) among treatments were already apparent at Day 15 (Fig. 1). Although growth rates were not calculated for
Table 1. Chemical properties of sediments used in Expts 1 and 2. Percentages represent percentage of unbaked sediment used. TC, TN = total carbon and nitrogen, respectively

\begin{tabular}{|lccc|}
\hline $\begin{array}{l}\text { Treatment } \\
(\%)\end{array}$ & $\begin{array}{c}\mathrm{TC} \\
\left(\mathrm{mg} \mathrm{g}^{-1}\right)\end{array}$ & $\begin{array}{c}\mathrm{TN} \\
\left(\mathrm{mg} \mathrm{g}^{-1}\right)\end{array}$ & $\begin{array}{c}\text { Protein } \\
\left(\mathrm{mg} \mathrm{g}^{-1}\right)\end{array}$ \\
\hline Expt 1 & & & \\
20 & 11.48 & 1.50 & 1.1 \\
40 & 21.41 & 2.49 & 2.2 \\
60 & 31.35 & 3.48 & 3.4 \\
80 & 41.29 & 4.47 & 4.6 \\
100 & 51.22 & 5.46 & 5.7 \\
Expt 2 & & & \\
12.5 & 11.16 & 1.16 & 0.2 \\
25 & 21.88 & 2.09 & 1.3 \\
32.5 & 32.59 & 3.02 & 2.5 \\
50 & 43.31 & 3.96 & 3.6 \\
62.5 & 54.03 & 4.89 & 4.7 \\
75 & 64.74 & 5.82 & 5.8 \\
87.5 & 71.17 & 6.75 & 7.0 \\
100 & 86.18 & 7.69 & 8.1 \\
\hline
\end{tabular}

this initial period (larvae were not measured), the significantly larger sizes of worms in the higher protein concentrations indicate higher growth rates. For the first period in which growth rates were measured (Days 15 to 23), growth rates were still higher in sediments with higher protein concentration (Fig. 2). However, growth rates decreased over time and this decrease was more dramatic in the sediments with higher protein concentration. LOWESS regression of growth rate over time shows the steep drop in the 80 and $100 \%$ treatments (Fig. 3). As a result, in subsequent sampling periods, growth rates were higher in intermediate treatments. However, at all sampling dates worms in the 80 and $100 \%$ treatments were

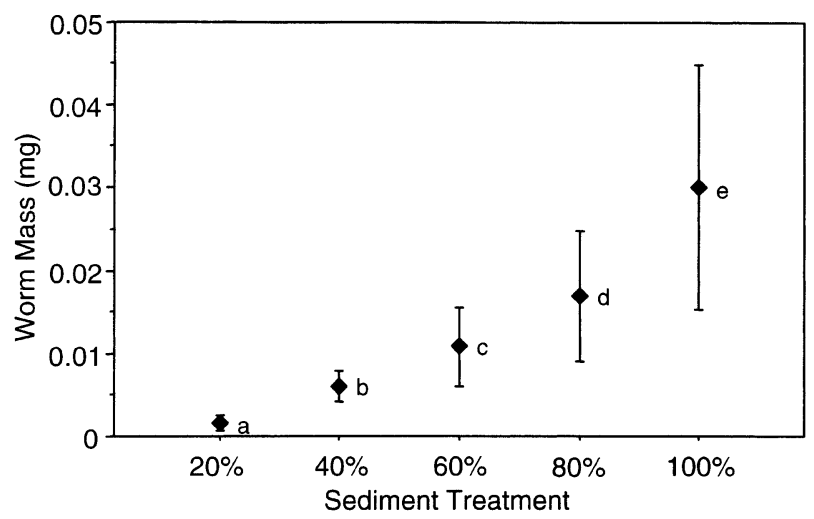

Fig. 1. Capitella sp. I. Worm size by treatment on Day 15 of Expt 1 . Data are means $\pm 1 \mathrm{SD}$. All means are significantly different, as indicated by group letters (based on ANOVA with 1 square-root data transformation). $20-100 \%$ = proportions of unbaked sediment used (see 'Materials and methods: Expt 1' for details) 


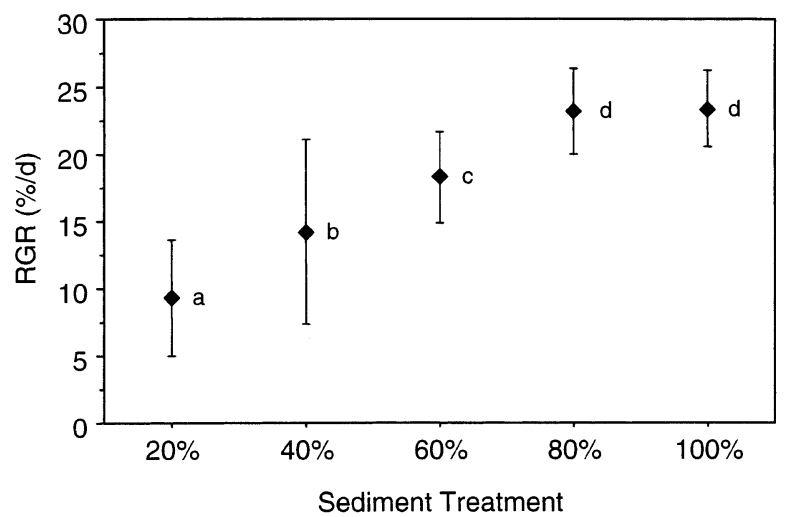

Fig. 2. Capitella sp. I. Relative growth rate (RGR) by treatment for Sampling Period 1 (Days 15 to 23) of Expt 1. Data are means $\pm 1 \mathrm{SD}$. Means sharing same letter are not significantly different

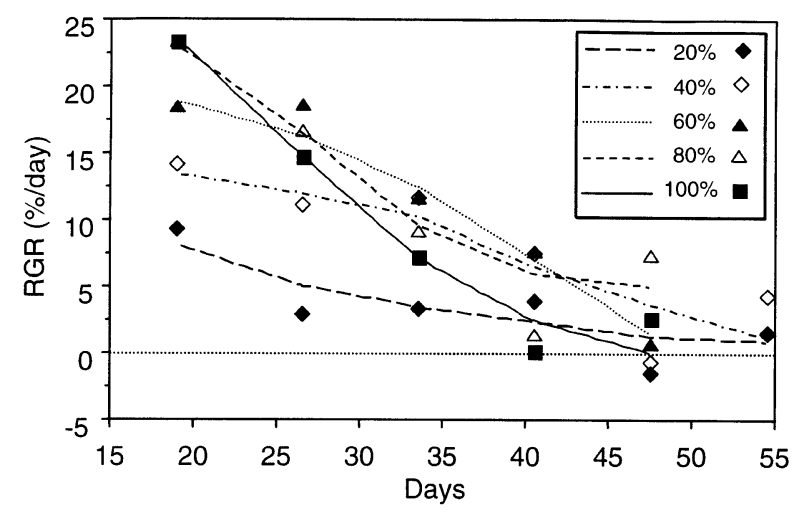

Fig. 3. Capitella sp. I. LOWESS regression of relative growth rate (RGR) vs sampling day for Expt 1 . Scatter points have been removed for clarity. Data points shown are arithmetic means of RGR for each treatment $\times$ day. Key shows percentage unbaked sediment

largest due to the head start conferred by higher early growth rates (Fig. 4). Worm sizes were compared statistically for each of the first 3 sampling dates. After this point, worms were being taken from dishes prior to the planned sampling date due to brood tube formation. ANOVA of worm size shows that worms in sediments with higher protein concentration were significantly larger than worms in the lower concentrations on all three sampling dates (Fig. 4).

\section{Egg production}

No females produced larvae in the $20 \%$ treatment. Worms in this treatment barely maintained their initial size. Among the other treatments, mean sizes of brood-

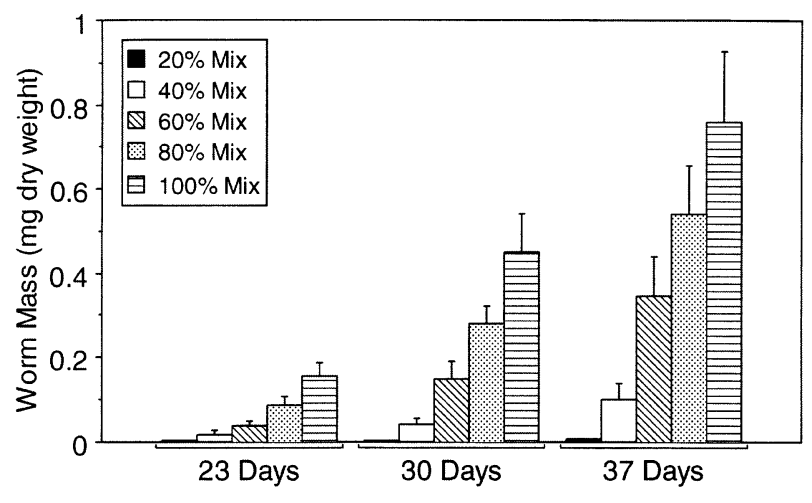

Fig. 4. Capitella sp. I. Worm sizes for the first 3 sampling days. Data are means of 10 dishes per treatment +1 SD. For each sampling day, all means are significantly different (based on 1-way ANOVA, data were square-root transformed)

ing females were larger in sediments with higher protein concentrations (Fig. 5A), although the difference between the 80 and $100 \%$ treatments was not significant. Females in sediments with higher protein concentration produced more embryos, independent of body size (Fig. 5B). The ANCOVA procedure allows us to calculate an adjusted value for embryo number which removes the effect of worm size. The adjusted value is the number of embryos that would be predicted for each worm if that worm's size was equal to the grand mean of worm size (Huitema 1980). Adjusted brood sizes were significantly different among all sediment treatments (Fig. 5B). Worms in the highest treatment $(100 \%)$ produced almost 2.5 times the number of embryos per brood as those in the lowest treatment $(40 \%)$. Embryo sizes, however, were not significantly different among any of the treatments (Fig. 6A). ANOVA of embryo sizes for broods sampled while in early development also showed no significant differences among treatments.

Females in higher sediment protein concentrations also produced their first brood earlier than those in lower concentrations. Each successive increase in sediment protein concentration led to a significant decrease in time to first reproduction (Fig. 6B), with worms in the $100 \%$ treatment enjoying a several day advantage over worms in the next highest treatment $(80 \%)$.

\section{Expt 2}

\section{Sediment chemistry}

Values of sediment chemistry (based on linear regression) are listed in Table 1 . The coefficients of determination $\left(\mathrm{r}^{2}\right)$ for all regressions were $>0.95$. 

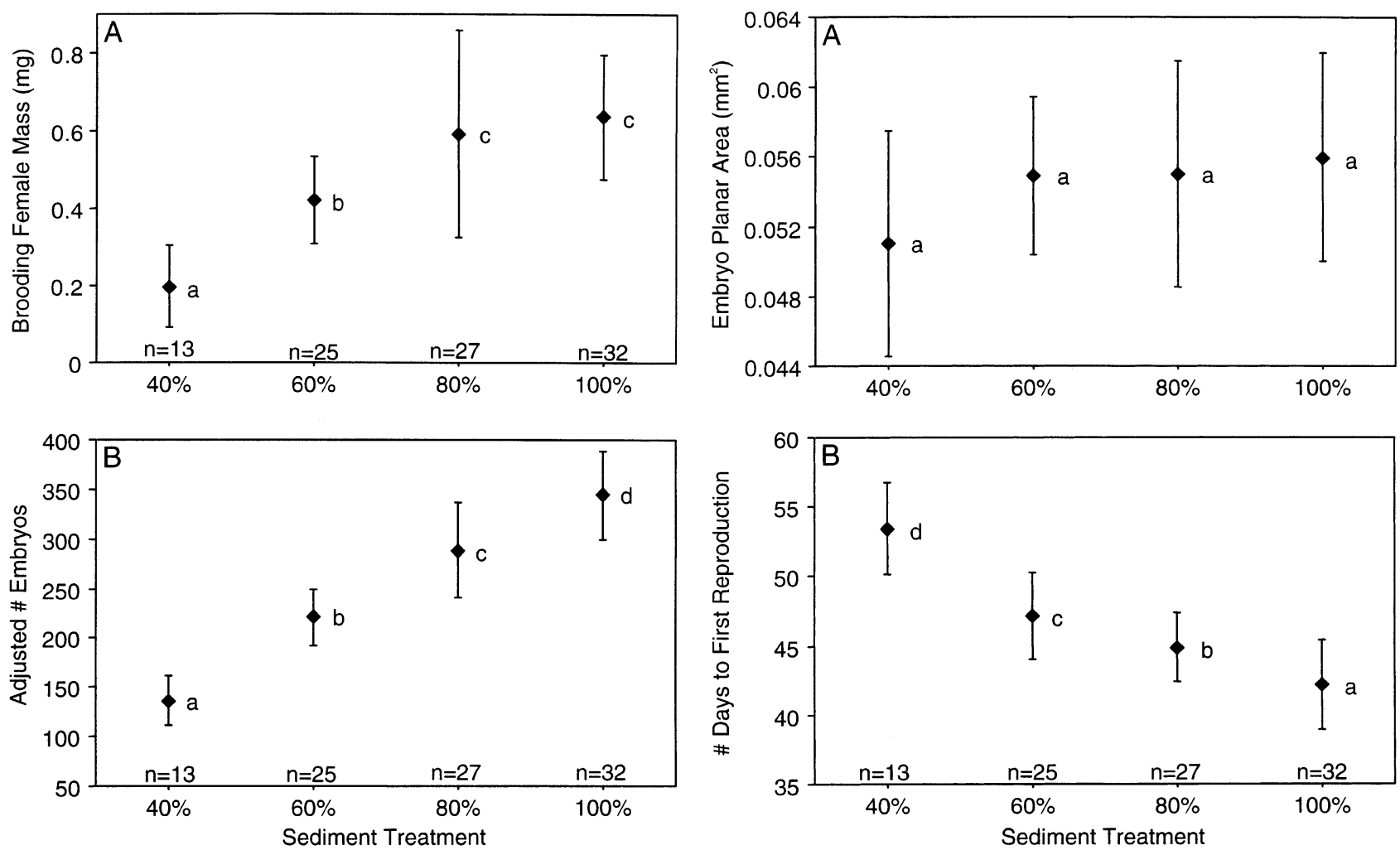

Fig. 5. Capitella sp. I. Reproduction data for Expt 1. (A) Dry weights of brooding females; dry weights were reciprocaltransformed for ANOVA; (B) adjusted number of embryos produced in the first brood (based on ANCOVA with brooding female dry weights as covariate). Data are means $\pm 1 \mathrm{SD}_{\text {; }}$ $\mathrm{n}=$ number of replicate dishes. Means sharing same letter are not significantly different

\section{Feeding rate}

Feeding rates were higher in sediments with higher protein concentration throughout the first 5 treatments (protein concentration range of 0.2 to $4.7 \mathrm{mg} \mathrm{g}^{-1}$ ). Although the groupings of significance were different, both ANOVA of specific feeding rates (Fig. 7A) and ANCOVA of dish total feeding rates (Fig. 7B) show this general trend. However, among the 4 highest protein concentration treatments $\left(\geq 4.7 \mathrm{mg} \mathrm{g}^{-1}\right)$, there were no significant differences in feeding rates based on either analysis.

\section{Growth}

Mean relative growth rates during the $10 \mathrm{~d}$ of Expt 2 were higher in sediments with higher protein concentration throughout the first 5 sediment treatments (rising from $\sim 8.5$ to $\sim 22.0 \% \mathrm{~d}^{-1}$ over a sediment protein concentration range of 0.2 to $4.7 \mathrm{mg} \mathrm{g}^{-1}$ ) but then lev-

Fig. 6. Capitella sp. I. Reproduction data for Expt 1. (A) Embryo planar areas; (B) number of days to production of the first brood. Data are means $\pm 1 \mathrm{SD} ; \mathrm{n}=$ number of replicate dishes. Means sharing same letter are not significantly different

eled off above this concentration (Fig. 8). A small (but statistically significant) decrease in growth rate was seen in the $87.5 \%$ treatment. This is most likely a statistical artifact which would disappear at higher levels of replication. If decreases in oxygen concentrations or build-up of toxic metabolites due to higher bacterial activity in the very rich sediments were occurring in the $87.5 \%$ treatment, we would expect the effects to be equal or greater in the $100 \%$ treatment.

\section{DISCUSSION}

Previous research has led to the hypothesis that the disappearance of Capitella sp. I when organic enrichment ceases is due to dramatic decreases in fitness as sediment organic concentration drops (e.g. Thistle 1981). We measured 3 components of fitness (feeding rate, growth rate, and reproduction) in sediments differing only in the concentration of available 'energy'. Each of these 3 components has the potential to dramatically influence population dynamics, and their responses to changes in sediment organic concentra- 

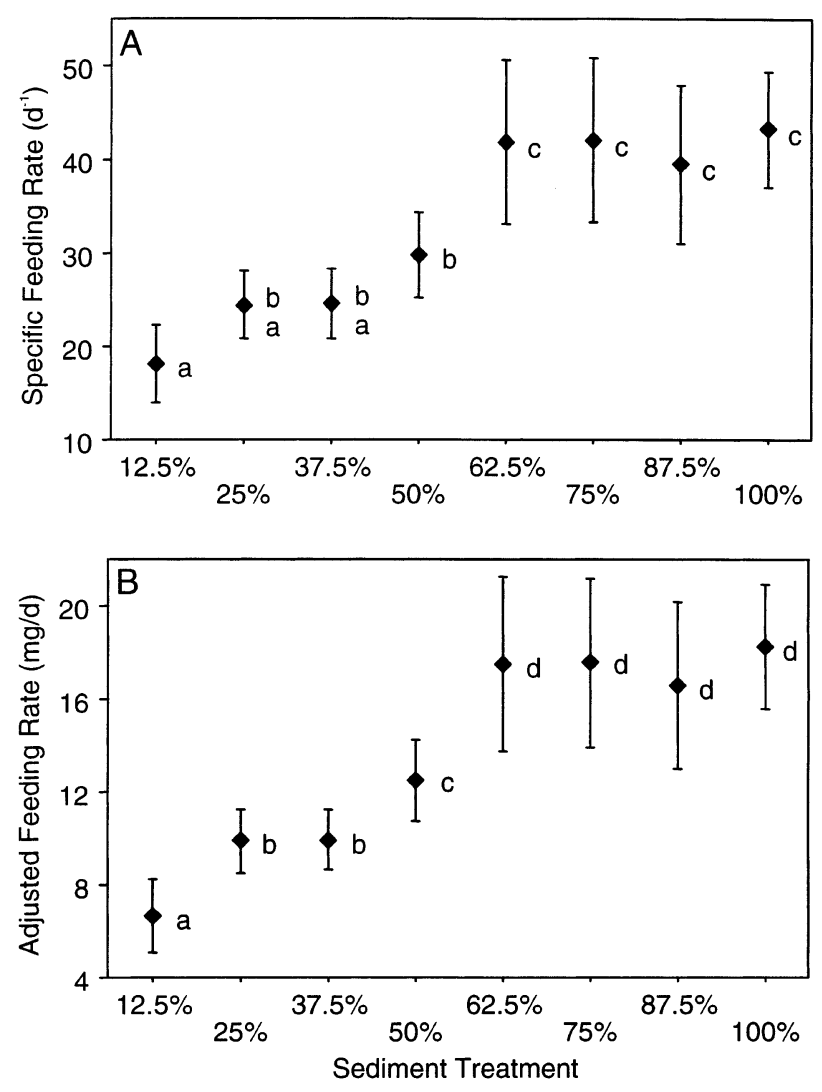

Fig. 7. Capitella sp. I. Feeding rate data for Expt 2. (A) Specific feeding rate; (B) adjusted bulk feeding rate (based on ANCOVA with geometric mean size as covariate). Data are means $\pm 1 \mathrm{SD} ; \mathrm{n}=7$ or 8 dishes. Means sharing same letter are not significantly different (see 'Materials and methods: Expt 2') for details of sediment preparation

tion may influence the success of Capitella sp. I in differing environments.

The development of optimal foraging theory for deposit feeders indicates that, in order to maximize energy intake in sediments of different organic concentrations, deposit feeders must alter feeding rate, trading off between absorption efficiency (getting the most from each volume of sediment processed) and throughput time (processing larger volumes of sediment). Previous research (Forbes \& Lopez 1987, Forbes et al. 1994) had suggested that Capitella sp. I possesses a rather limited ability to alter feeding rate in response to changes in sediment organic concentration. The potential implication of this observation was that Capitella sp. I would not be able to maintain energy intake rates as sediment organic concentration decreased. Dade et al.'s (1990) optimal foraging model, based on performance analysis of guts behaving like continuous plug-flow chemical reactors, indicates that maximum absorption of digestive products is achieved

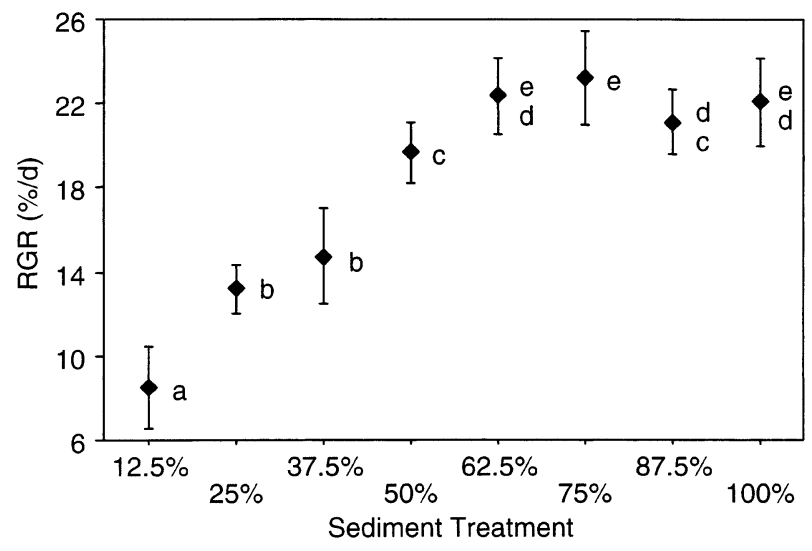

Fig. 8. Capitella sp. I. Relative growth rates (RGR) for Expt 2. Data are dish means $\pm 1 \mathrm{SD} ; \mathrm{n}=7$ or 8 dishes. Means sharing same letter are not significantly different

by increasing feeding rate as food quality (relevant nutrient concentrations) increases, reaching a maximum at some intermediate concentration, and then decreasing feeding rate as concentrations exceed this critical value. Capitella sp. I did not show the predicted peak in feeding rate in our experiment. Instead, feeding rates of Capitella sp. I increased as sediment protein concentration increased throughout the range of 0.2 to $4.7 \mathrm{mg} \mathrm{g}^{-1}$, but then leveled off, with no decrease in feeding rate past the 'critical level' at which this asymptote was reached. This pattern does not follow the predicted 'optimal' functional response curve. Therefore, it appears that Capitella sp. I may be feeding suboptimally in sediments with very high organic concentration. However, in terms of our hypothesis of decreasing fitness as sediment protein concentration decreases, it is the other end of the response curve which is of interest. Capitella sp. I does decrease feeding rate as sediment concentration decreases, which is consistent with the optimal foraging predictions. Therefore, we reject this behavioral component as a contributing factor to Capitella sp. I's disappearance in low-quality sediments.

We know that growth rates of Capitella sp. I differ in sediments of different quality (e.g. Tenore 1983, Grémare et al. 1988, Forbes \& Lopez 1990, Bridges et al. 1994, Horng 1998), and we know that larger females produce greater numbers of eggs (Bridges et al. 1994, Grémare 1994). Therefore, the relationship between sediment quality and growth rate is a key component of fitness. Extensive studies have been done on the effect of sediment 'quality' on both individual and population growth rates of Capitella sp. I. In most previous experiments the quality of sediment was varied by using different sources of organic matter. Worms grew faster when fed sediments that had higher nutritional value (measured as nitrogen or protein concentration) 


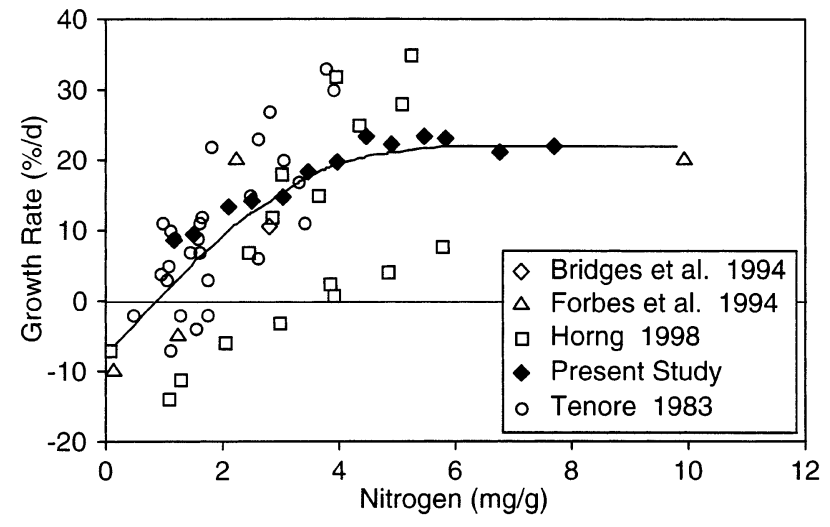

Fig. 9. Capitella sp. I. Growth rates vs sediment nitrogen concentrations (with LOWESS regression) for previous studies and present study. Many of the data points are based on estimates taken from graphs. LOWESS regression line is based on all data points

(Tenore 1983, Grémare et al. 1988, Forbes \& Lopez 1990, Bridges et al. 1994, Horng 1998). The source of organic matter was also shown to be important, independent of nitrogen or protein concentration. Different growth rates have been seen for worms feeding on sediments with the same concentration, but different sources, of organic matter (Phillips \& Tenore 1984, Tsutsumi et al. 1990). Fig. 9 demonstrates the wide range of variation seen in reported growth rates over a range of nitrogen concentration (the most frequently reported measure of sediment quality). Clearly, the distinction must be made between the concentration of total organic matter (based on any measurement) and the concentration of bioavailable organic matter. This is the main reason why we feel the biomimetic EHAA technique of Mayer et al. (1995) should be the preferred method of measuring sediment quality.

Our experiments avoided this problem by using sediments which varied only in the concentration of available protein. In both experiments, initial growth rates of Capitella sp. I were progressively higher in sediments with higher protein concentration throughout the range of $1.1 \mathrm{mg} \mathrm{g}^{-1}$ to $4.6-4.7 \mathrm{mg} \mathrm{g}^{-1}$, but reached a plateau at approximately $22 \% \mathrm{~d}^{-1}$ in sediments at or above this concentration. Growth rates decreased over time for all sediment treatments in Expt 1 (which is expected as the worms grow larger), but the decrease was most pronounced for the 80 and $100 \%$ treatments. It is likely that higher early growth rates in the 80 and $100 \%$ treatments allowed worms in these treatments to reach reproductive size more quickly and then switch from investing food in somatic growth to investing in reproductive products.

This pattern of variation in growth rates as sediment quality varies has 2 important implications for popula- tion dynamics. The first is that reproductive individuals in sediments with higher organic concentrations will be larger. Both previous experiments (Bridges et al. 1994, Grémare 1994) and the present study have shown that larger females of Capitella sp. I produce more offspring. The second important result of increased growth rate is that individuals in higher-quality sediments will reach adult/reproductive size more quickly and will produce their first brood earlier than those in lower-quality sediments. This effect was seen in our experiments. Worms in sediments with the highest organic concentration produced their first brood as early as $5 \mathrm{wk}$, while worms in the lower organic concentrations averaged $>6$ wk. Levin et al. (1996) saw first reproduction in Capitella sp. I occur as early as $4 \mathrm{wk}$ in sediments amended with sewage. Time to first reproduction can be an important component of fitness (Lewontin 1965, Stearns \& Koella 1986). Levin et al. (1996) used life-table analysis to investigate the importance of different life-history parameters in population growth rates. They found that the explosive population increases seen in Capitella sp. I were due mostly to reduced maturation time and increases in age-specific fecundity in organically enriched sediments. The converse is also true, decreases in Capitella sp. I population sizes will result from reduced brood size produced by smaller adults and increases in generation time in lower-quality sediments. These results are consistent with the resource-depletion hypothesis.

The most direct component of fitness is, of course, offspring production. Our experiments confirmed that worms in higher-quality sediments produce more offspring by virtue of their larger size. But it was also shown that females in the sediments with higher protein concentration produced more larvae in the first brood independent of female size. As sediment protein concentration increased, worms invested progressively greater proportions of food into reproduction. The specialized vitellogenic pathways which enable opportunistic species to rapidly allocate any excess energy (beyond maintenance ration) directly into reproduction is one of the key features allowing their characteristic explosive population growth (Eckelbarger 1994).

Perhaps the more important result of the reproduction experiments is that Capitella sp. I did not reproduce in sediment with $1.1 \mathrm{mg}$ protein $\mathrm{g}^{-1}$ throughout the duration of Expt 1 (2 mo). Tsutsumi (1990) found that very few individuals of Capitella sp. I could reach a reproductively competent body size in sediments with a protein concentration of $<3 \mathrm{mg} \mathrm{g}^{-1}$. Cohen \& Pechenik (1999) similarly found that Capitella sp. I was unable to reproduce in sediments of low organic concentration. Although we cannot pinpoint the level of sediment organic concentration necessary for Capitella sp. I to achieve a 'normal' reproductive cycle (and 
it seems likely that this level will vary based on environmental conditions), it is apparent that there is some threshold below which Capitella sp. I cannot reproduce. Worms in our lowest treatment were surviving and continued to grow very slowly, so it is possible that they might eventually have been able to produce a small number of larvae. Capitella sp. I females have sometimes been observed to produce only 1 or 2 eggs after several months in sediments of low organic concentration (J. Grassle pers. comm.). Clearly, however, if sediment organic concentration drops below the threshold organic concentration needed for reproduction, Capitella sp. I populations will disappear from the site.

It is clear that growth rate and fecundity of Capitella sp. I are influenced by sediment organic concentration in a manner that will impact their population dynamics. Now that we have systematically documented the responses of feeding rate, growth rate, and reproductive output to changes in sediment protein concentrations for an opportunistic species, we should compare these responses to those of an equilibrium species. Comparisons of this type might elucidate important factors influencing species distributions and successional trends. Similar experiments have been conducted with the equilibrium deposit-feeding polychaete Abarenicola pacifica (Linton \& Taghon in press) and such a comparison will be the focus of a future study (Linton \& Taghon unpubl. data).

Acknowledgements. This research was supported by USEPA grant R823575-01. We thank Ching-Yi Horng for instruction in techniques for working with Capitella sp. I and Judith P. Grassle for comments on the manuscript.

\section{LITERATURE CITED}

Bridges TS (1996) Effects of organic additions to sediment, and maternal age and size, on patterns of offspring investment and performance in two opportunistic deposit-feeding polychaetes. Mar Biol 125:345-357

Bridges TS, Levin LA, Cabrera D, Plaia G (1994) Effects of sediment amended with sewage, algae, or hydrocarbons on growth and reproduction in two opportunistic polychaetes. J Exp Mar Biol Ecol 177:99-119

Calow P (1982) Homeostasis and fitness. Am Nat 120:416-419

Cammen LM (1989) The relationship between ingestion rate of deposit feeders and sediment nutritional value. In: Lopez G, Taghon G, Levinton J (eds) Ecology of marine deposit feeders. Springer-Verlag, New York, p 201-222

Cleveland WS (1979) Robust locally weighted regression and smoothing scatterplots. J Am Stat Assoc 74:829-836

Cleveland WS (1981) LOWESS: a program for smoothing scatterplots by robust locally weighted regression. Am Stat 35:54

Cohen RA, Pechenik JA (1999) Relationship between sediment organic content, metamorphosis, and postlarval performance in the deposit-feeding polychaete Capitella sp. I. J Exp Mar Biol Ecol 240:1-18
Dade WB, Jumars PA, Penry DL (1990) Supply-side optimization: maximizing absorptive rates. In: Hughes RN (ed) Behavioural mechanisms of food selection. Springer-Verlag, Berlin, p 531-556

Dubilier N (1988) $\mathrm{H}_{2} \mathrm{~S}$ - a settlement cue or a toxic substance for Capitella sp. I larvae? Biol Bull 174:30-38

Eckelbarger KJ (1986) Vitellogenic mechanisms and the allocation of energy to offspring in polychaetes. Bull Mar Sci 39:426-443

Eckelbarger KJ (1994) Diversity of metazoan ovaries and vitellogenic mechanisms: implications for life history theory. Proc Biol Soc Wash 107:193-218

Eckelbarger KJ, Linley PA, Grassle JP (1984) Role of ovarian follicle cells in vitellogenesis and oocyte resorption in Capitella sp. I (Polychaeta). Mar Biol 79:133-144

Forbes TL, Lopez GR (1987) The allometry of deposit feeding in Capitella species I (Polychaeta: Capitellidae): the role of temperature and pellet weight in the control of egestion. Biol Bull 172:187-201

Forbes TL, Lopez GR (1990) The effect of food concentration, body size, and environmental oxygen tension on the growth of the deposit-feeding polychaete, Capitella species I. Limnol Oceanogr 35:1535-1544

Forbes TL, Forbes VE, Depledge MH (1994) Individual physiological responses to environmental hypoxia and organic enrichment: implications for early soft-bottom community succession. J Mar Res 52:1081-1100

Grassle JF, Grassle JP (1974) Opportunistic life histories and genetic systems in marine benthic polychaetes. J Mar Res 32:253-284

Grassle JP, Grassle JF (1976) Sibling species in the marine pollution indicator Capitella (Polychaeta). Science 192: 567-569

Grassle JF, Grassle JP (1977) Temporal adaptations in sibling species of Capitella. In: Coull BC (ed) Ecology of marine benthos. The Belle W. Baruch Library in Marine Science. University of South Carolina Press, Columbia, p 177-189

Grémare A (1994) What describes fecundity of Capitella sp. I better: macro- or micronutrient availability? Mar Biol 119: 367-374

Grémare A, Marsh AG, Tenore KR (1988) Short-term reproductive responses of Capitella sp. I (Annelida: Polychaeta) fed on different diets. J Exp Mar Biol Ecol 123:147-162

Grémare A, Marsh AG, Tenore KR (1989a) Fecundity and energy partitioning in Capitella capitata type I (Annelida: Polychaeta). Mar Biol 100:365-371

Grémare A, Marsh AG, Tenore KR (1989b) Secondary production and reproduction of Capitella capitata type I (Annelida: Polychaeta) during a population cycle. Mar Ecol Prog Ser 51:99-105

Holbrook MJL, Grassle JP (1984) The effect of low density on the development of simultaneous hermaphroditism in male Capitella species I (Polychaeta). Biol Bull 166: 103-109

Horng CY (1998) Influence of the marine polychaete, Capitella sp. I, on the fate of sediment-bound polycyclic aromatic hydrocarbons - the role of feeding activity. PhD dissertation, Rutgers, the State University of New Jersey, New Brunswick, NJ

Huitema BE (1980) The analysis of covariance and alternatives. John Wiley \& Sons, New York

Levin LA (1984) Life-history and dispersal patterns in a dense infaunal polychaete assemblage: community structure and response to disturbance. Ecology 65:1185-1200

Levin LA, Caswell H, Bridges T, DiBacco C, Cabrera D, Plaia G (1996) Demographic responses of estuarine polychaetes to pollutants: life table response experiments. Ecol Appl 6:1295-1313 
Lewontin RC (1965) Selection for colonizing ability. In: Baker HG, Stebbins GL (eds) The genetics of colonizing species. Academic Press, New York, p 79-94

Linton DL, Taghon GL (in press) Feeding, growth, and fecundity of Abarenicola pacifica in relation to sediment organic concentration. J Exp Mar Biol Ecol

Marsh AG, Grémare A, Tenore KR (1989) Effect of food type and ration on growth of juvenile Capitella sp. I (Annelida: Polychaeta): macro- and micronutrients. Mar Biol 102: 519-527

Mayer LM, Schick LL, Sawyer T, Plante CJ, Jumars PA, Self RL (1995) Bioavailable amino acids in sediments: a biomimetic, kinetics-based approach. Limnol Oceanogr 40: 511-520

McCall PL (1977) Community patterns and adaptive strategies of the infaunal benthos of Long Island Sound. J Mar Res 35:221-266

Pearson TH, Rosenberg R (1978) Macrobenthic succession in relation to organic enrichment and pollution of the marine environment. Oceanogr Mar Biol Annu Rev 16:229-311

Phillips NW (1984) Compensatory intake can be consistent with an optimal foraging model. Am Nat 123:867-872

Phillips NW, Tenore KR (1984) Effects of food-particle size and pelletization on individual growth and larval settlement of the deposit feeding polychaete Capitella capitata Type I. Mar Ecol Prog Ser 16:241-247

Radford PJ (1967) Growth analysis formulae - their use and abuse. Crop Sci 7:171-175

Stearns SC, Koella JC (1986) The evolution of phenotypic plasticity in life-history traits: predictions of reaction norms for age and size at maturity. Evolution 40:893-913

Taghon GL (1981) Beyond selection: optimal ingestion rate as a function of food value. Am Nat 118:202-214

Editorial responsibility: Lisa Levin (Contributing Editor), La Jolla, California, USA
Taghon GL, Greene RR (1990) Effects of sediment-protein concentration on feeding and growth rates of Abarenicola pacifica Healy et Wells (Polychaeta: Arenicolidae). J Exp Mar Biol Ecol 136:197-216

Taghon GL, Greene RR, Bard D (1990) Effects of food value of artificial and natural sediments on functional response and net rate of energy gain by a deposit-feeding polychaete. In: Hughes RN (ed) Behavioural mechanisms of food selection. Springer-Verlag, Berlin, p 515-529

Tenore KR (1977) Utilization of aged detritus derived from different sources by the polychaete Capitella capitata. Mar Biol 44:51-55

Tenore KR (1981) Organic nitrogen and caloric content of detritus. I. Utilization by the deposit-feeding polychaete, Capitella capitata. Estuar Coast Shelf Sci 12:39-47

Tenore KR (1983) Organic nitrogen and caloric content of detritus. III. Effect on growth of a deposit feeding polychaete, Capitella capitata. Estuar Coast Shelf Sci 17: 733-742

Tenore KR, Chesney EJ Jr (1985) The effects of interaction of rate of food supply and population density on the bioenergetics of the opportunistic polychaete, Capitella capitata (Type I). Limnol Oceanogr 30:1188-1195

Thistle D (1981) Natural physical disturbances and communities of marine soft bottoms. Mar Ecol Prog Ser 6: $223-228$

Tsutsumi H (1990) Population persistence of Capitella sp. (Polychaeta; Capitellidae) on a mud flat subject to environmental disturbance by organic enrichment. Mar Ecol Prog Ser 63:147-156

Tsutsumi H, Fukunaga S, Fujita N, Sumida M (1990) Relationship between growth of Capitella sp. and organic enrichment of the sediment. Mar Ecol Prog Ser 63:157-162

Submitted: October 20, 1999; Accepted: April 4, 2000

Proofs received from author(s): September 25, 2000 